\title{
地下水と統合水資源管理
}

\author{
廣木 謙三*1
}

\section{Integrated Water Resources Management for better groundwater management}

\author{
Kenzo HIROKI*1
}

\begin{abstract}
Groundwater, finite source on the earth, has been utilized as handy and cost-effective water sources by various sectors. Global change including population growth and climate change will add pressure to groundwater stress which already exists in many parts of the world. Integrated Water Resources Management will help implementing sustainable, better groundwater management by reducing inefficient use of water and promoting flexible development of surface and ground water resources. Integration of surface water and groundwater through IWRM should happen at four different phases, i.e., formulation of legal framework and policy; planning and implementation; public involvement and stakeholder participation; and information sharing and disclosure. The paper explains how the integration should happen and what outcomes are expected in each of the phases. Example of international contribution through IWRM of groundwater is also explained.
\end{abstract}

Key words: groundwater, integrated water resources management, climate change, information sharing, stakeholder involvement

\section{I 身近にある地下水}

水の惑星といわれる地球だが，人間が実際に 使える水の量はそう多くはない。地球上の水の $99 \%$ は海水などの塩水である。仮に地球の水がバ スタブ 1 杯の水であったなら，全地下水の量はミ ネラルウォーター 1 本分 (全体の $0.8 \%$ )に過ぎず, 地表水は打猪口 1 杯分（全体の $0.01 \%$ ）に過ぎな い (Fig. 1)。

身近な水資源である地下水は，その特性に応 じて，地域の状況を踏まえて多様に活用されてき た。日本と世界各地のコミュニティーは，それを
取り巻く自然環境や社会状況に応じて地表水と地 下水を賢く使い分けてきた。しかし, 経済が発展 し, 社会構造が広域化・複雑化するにつ水管理 も高度化, 分業化し, 何時しか工業, 農業, 発電 などそれぞれの用途に応じて地下水と地表水は分 離して扱われ，管理されるようになった。世界 では飲料用の $50 \%$, 工業用の $40 \%$, かんがい用 水の $20 \%$ の水がそれぞれ地下水に依存している (Fig. 2)。我が国においても Fig. 3 に示すように 年間約 120 億卜ンの地下水がそれぞれ 3 割弱程度, 都市用水，工業用水，農業用水などに使われてき ている。我が国の地下水利用は Fig. 4 に示すよう

* 1 内閣府参事官 Director for Infrastructure and Exploration, Bureau for Science and Technology, Cabinet Office 前国連本部経済社会局国際顧問（国連水と衛生に関する諮問委員会事務局長

Former Head of Secretariat, United Nations Secretary-General's Advisory Board on Water and Sanitation 


\section{地球の水がバスタブー杯の水だったら..}

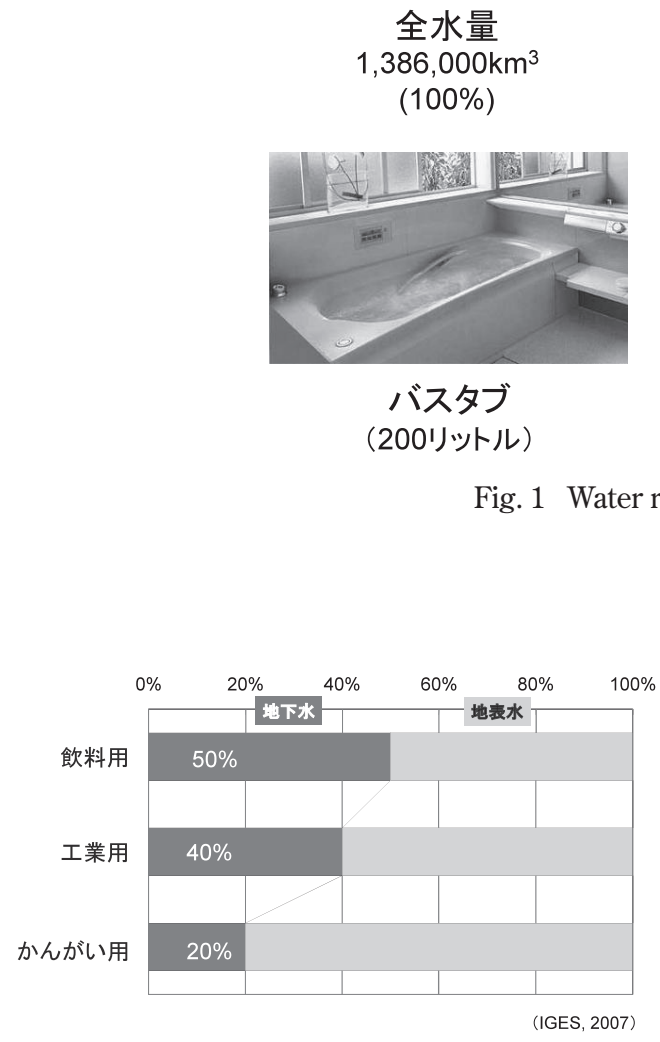

$\begin{array}{cc}\text { 地下水 } & \text { 地表水 } \\ 10,530 \mathrm{~km}^{3} & 117 \mathrm{~km}^{3} \\ (0.8 \%) & (0.01 \%)\end{array}$

ボトル

(1.5リットル)

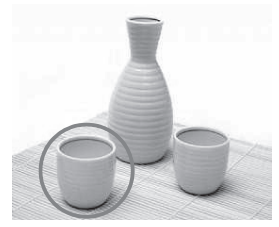

御猪口

(20cc)

Fig. 2 Share of groundwater in global water resources

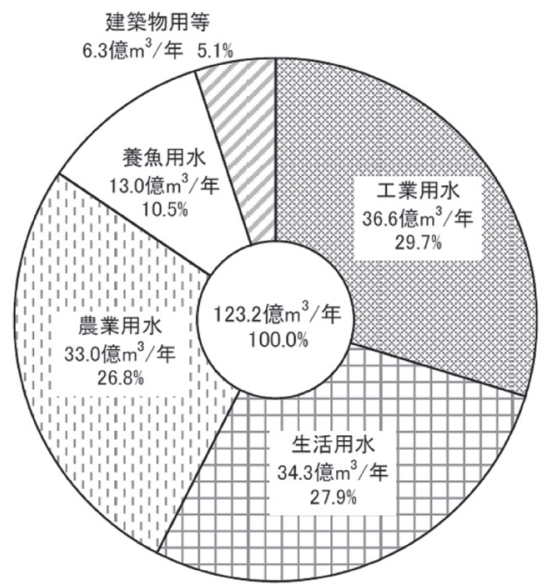

（国土交通省土地·水資源局水資源部，2009）

Fig. 3 Water use by sectors in Japan

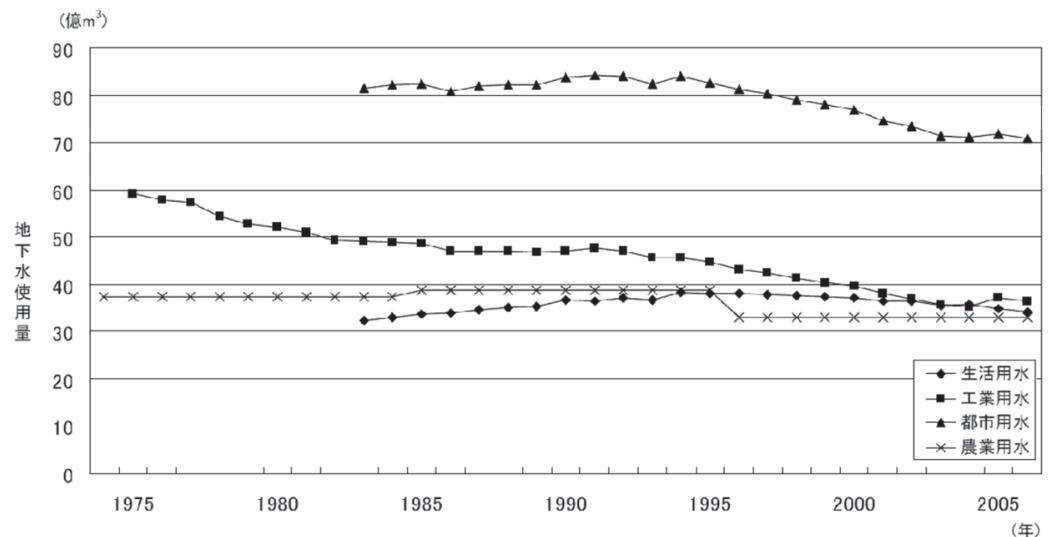

（国土交通省土地-水資源局水資源部，2009）

Fig. 4 Trend of groundwater use in Japan 


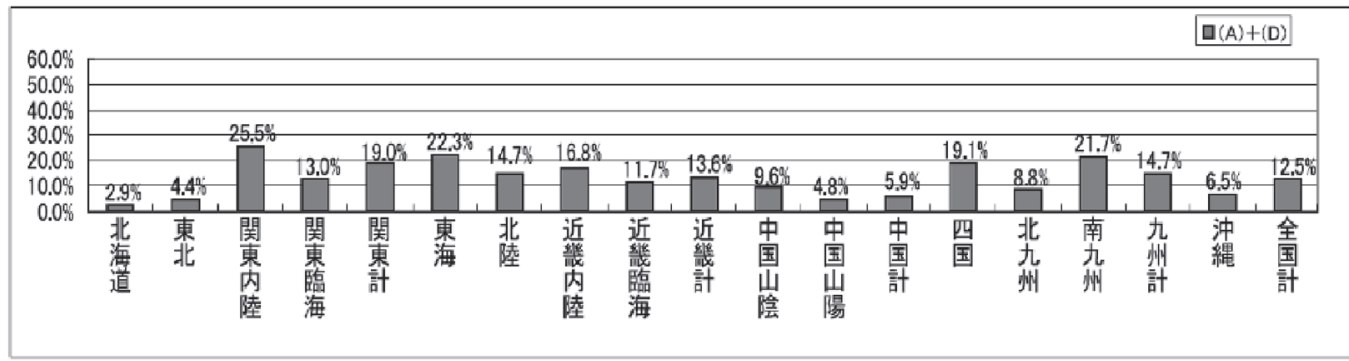

（国土交通省土地·水資源局水資源部，2009）

Fig. 5 Dependence rate on groundwater by region

に 1990 年に 80 億トンだった都市用水への利用が 2002 年に 70 億トン程度になるなど，総じて微減 してきたが，近年ではその変化は横ばいに転じて きている，また Fig. 5 に示すように，地下水依存 率は北海道の $2.9 \%$ に対して南九州の $21.7 \%$ など 地域によりに差がある。

\section{II 地下水を取り巻く状況}

近年の人口爆発を含む社会変化に加え，地球温 暖化による気候変化の兆候が現れるなど，地下水 を含む水資源を取り巻く環境は急激に変化してき ている。既に地球上では地域によって大きな水ス トレス（水供給量に対して水需要が過剰な状態）
が生じてきており，今後の人口増加や一人当たり 食糧消費量の増加により，ますます䩦しくなるも のと懸念されている。特に地球温暖化は頻発する 洪水や渴水など，地下水，地表水に直接的な影響 を及ぼすだけでなく，地表水と地下水の相互関係 や管理のあり方にまで強いインパクトを与えるこ とが懸念されている。世界各国の都市化に伴う地 表水の不足や使用水の未処理などにより，地下水 の過剰取水による地盤沈下や地下水質污染などの 問題が発生している。さらに加速的な人口増や経 済発展は水需要の急速な拡大を招き, 不足する地 表水を補うため，さらなる地下水への依存を強め てきている。Fig. 6 は各国各地域に打ける地下水 総取水量の年変化を示したものだが，インドや中

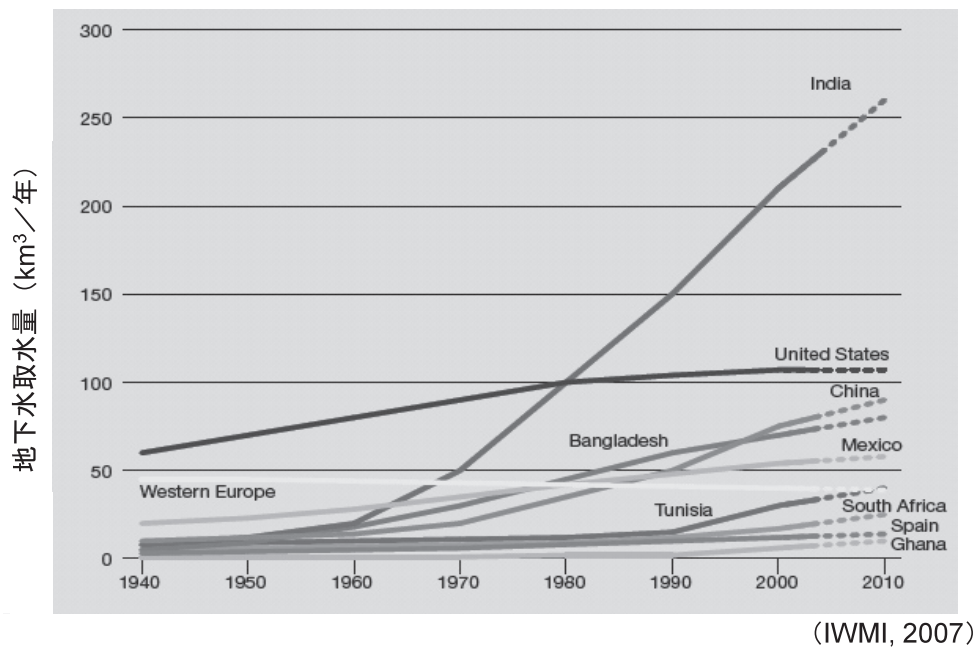

Fig. 6 Increasing groundwater use in selected states in the world 
国，メキシコといった急速に発展を遂げる新興国 を中心に地下水の取水量は急速に増加してきてお り，こうした状況下，用途に応じて地下水と地表 水を縦割りで管理することは，多くの地域におい て持続可能でなくなってきている。

\section{III 統合水資源管理 一より良い地下水管理の処方箋一}

地球温暖化の影響がさらに顕在化する今世紀, こうした問題に対処するために我々は今何をする べきだろうか。国際水社会はこの問題解決の方向 性として，統合水資源管理という概念を提示し ている。これは Fig. 7 に示すように地下水を含め た水に関わる全ての分野の活動の連携と調整を図 り，従来縦割りで管理されていた都市用水，灌溉 用水，環境用水といった水を分野横断的に統一し た方針のもとに管理していくものである。情報の 共有化と住民参加を促しつつ, 効率的な水管理を
図るこの概念は，今後の水管理のありかたを示す ものとして定着しつつある。大事なことは，地下 水管理を，この統合水資源管理を実行する上で極 めて重要な役割を果たす要素として位置づけ，気 候変動を含む自然と社会の変化に適応した地表水 と地下水の包括的かつ具体的な管理体系を構築す ることである。

この地表水と地下水の統合管理は, 以下の重要 な側面を含む。すなわち，政策及び制度面におけ る統合；情報共有化と公開における統合；計画と その実施に打ける統合 ; 住民の参画と活動におけ る統合である。Fig. 8 に示すように，これらの統 合は階層をなし，それぞれの活動に立脚して他の 活動が成り立っている。このため，それぞれの局 面で地下水管理と地表水管理の活動を一体化する とともに，そうした統合された活動が法制度面， 計画実施面，住民参加面，情報共有面といった階 層間でも整合を保っていく必要がある。

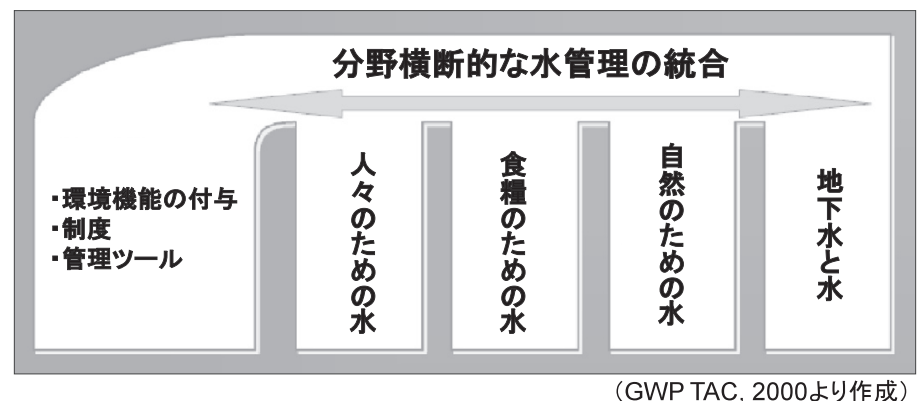

Fig. 7 Concept of Integrated Water Resources Management

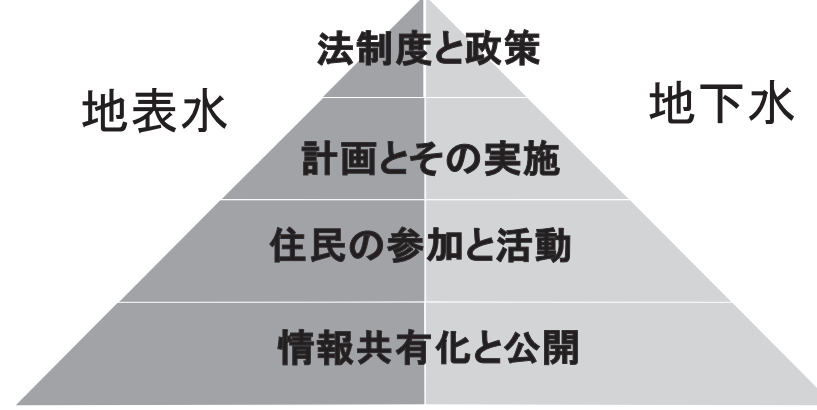

Fig. 8 Integration of surface water and groundwater management by IWRM 


\section{1．政策及び制度面における地表水と地下水の統}

合

法制度を含む政策面での検討には地下水の公水 として位置づけの議論を含むが，実務上肝要なこ とは，地表水と地下水の管理を統合するための仕 組み（組織，計画，予算）が明瞭に規定され，具 体化されているかである。Table 1 に示すように 関係国の例を見ても，制度の枠組みは地下水の公 的な位置づけと関係している。こうした諸外国の 事例と比較して，我が国の地下水が私水として位 置づけられていることなどから，地下水管理に関 して一本化された法体系にはなって打らず，個別 法の効果や財源の面などで検討すべき課題も見ら れる。

\section{2. 計画とその実施における地表水と地下水の統} 合

社会経済の変化への対応と気候変動への適応を 満足するために総合化された水資源管理計画は, 水需要と供給管理の統合，水資源施設の統合，水 量と水質管理の統合，地表水と地下水管理の統合 を果たさなければならない。その具体的な統合の 姿は，Fig. 9 に示すように森林・流域の保全から, 地下水の涵養，雨水·再生水管理との統合，水質 の一体管理，住民参加や情報の共有化などを含 み，流域全体にわたる総合的なアプローチが必要 である。
地表水と地下水管理の統合化にあたっては，共 有された情報を土台に，利害関係者の意見や提言 を踏まえながら，関係機関が協議を重ね計画作成， 実施，評価見直しのサイクルを積み重ね，スパイ ラル状に計画を進化させていくことが望まれる。 国土審議会水資源分科会調査企画部会では，そう した総合水資源管理の体系を Fig. 10 のように示 している。それによれば，総合水資源管理関係府 省連絡会議との連携調整を経て作成される基本方 針の下，対象流域が指定され，それぞれの流域に 設置された流域総合水資源管理協議会との協議等 を経て流域総合水資源管理基本計画が作成され， これに基づき河川管理者や利水者により具体的な 取り組みが実施されることとなっている。

また，こうした地表水，地下水の一体的管理に おいては渇水時，地震時などの様々なシナリオに 合わせて水源を組み合わせるとともに，新たな取 り組みや工夫，新技術などを積極的に取り入れて いくことも重要であり，例えば平常時や緊急時に 分けたシナリオに基づいて地下水と表流水を一体 管理することは有効と考えられる。すなわち Fig. 11 に示すように，同じ水需要量を満足するのに， 平常時はより多く表流水を使い，渴水や災害によ る表流水取水施設の被害などで使える表流水の量 が減少した場合にはその減少分を一時的な地下水 揚水量の増で補い，渴水が終了した時点で涵養等 により地下水賦存量を回復させる（なお，地震時

Table. 1 Groundwater management system and financial sources in selected countries 各国地下水法制度と地下水税・課徴金制度の例

\begin{tabular}{|c|c|c|c|}
\hline 国 名 & 法 律 & 法律の効果 & 地下水税 $\cdot$ 課徵金 \\
\hline オランダ & 地下水法 & $\begin{array}{l}\text { 揚水は許可制 } \\
\text { 州が地下水管理 }\end{array}$ & 州の地下水税 \\
\hline ドイツ & $\begin{array}{l}\text { 連邦水管理法 } \\
\text { 州水法 }\end{array}$ & $\begin{array}{l}\text { 地下水は個人財産だが, 公的 } \\
\text { 規制がかかる。 }\end{array}$ & $\begin{array}{l}\text { 水資源税 (バーデン・ヴュルテ } \\
\text { ンベルク州) }\end{array}$ \\
\hline $\begin{array}{l}\text { 米国 } \\
\left(\begin{array}{l}\text { テキサ } \\
\text { 州) }\end{array}\right.\end{array}$ & 州憲法 & 地域の地下水管理組織が規制 & 揚水量に応じ課徵金 \\
\hline 日本 & $\begin{array}{l}\text { 個別規制法はあるが, } \\
\text { 地下水法はない }\end{array}$ & $\begin{array}{l}\text { 水質, 揚水, 地盤沈下などの } \\
\text { 項目別に個別法等で規制 }\end{array}$ & 中央レベルでの税・課徵金なし \\
\hline
\end{tabular}

(IGES, 2007) 


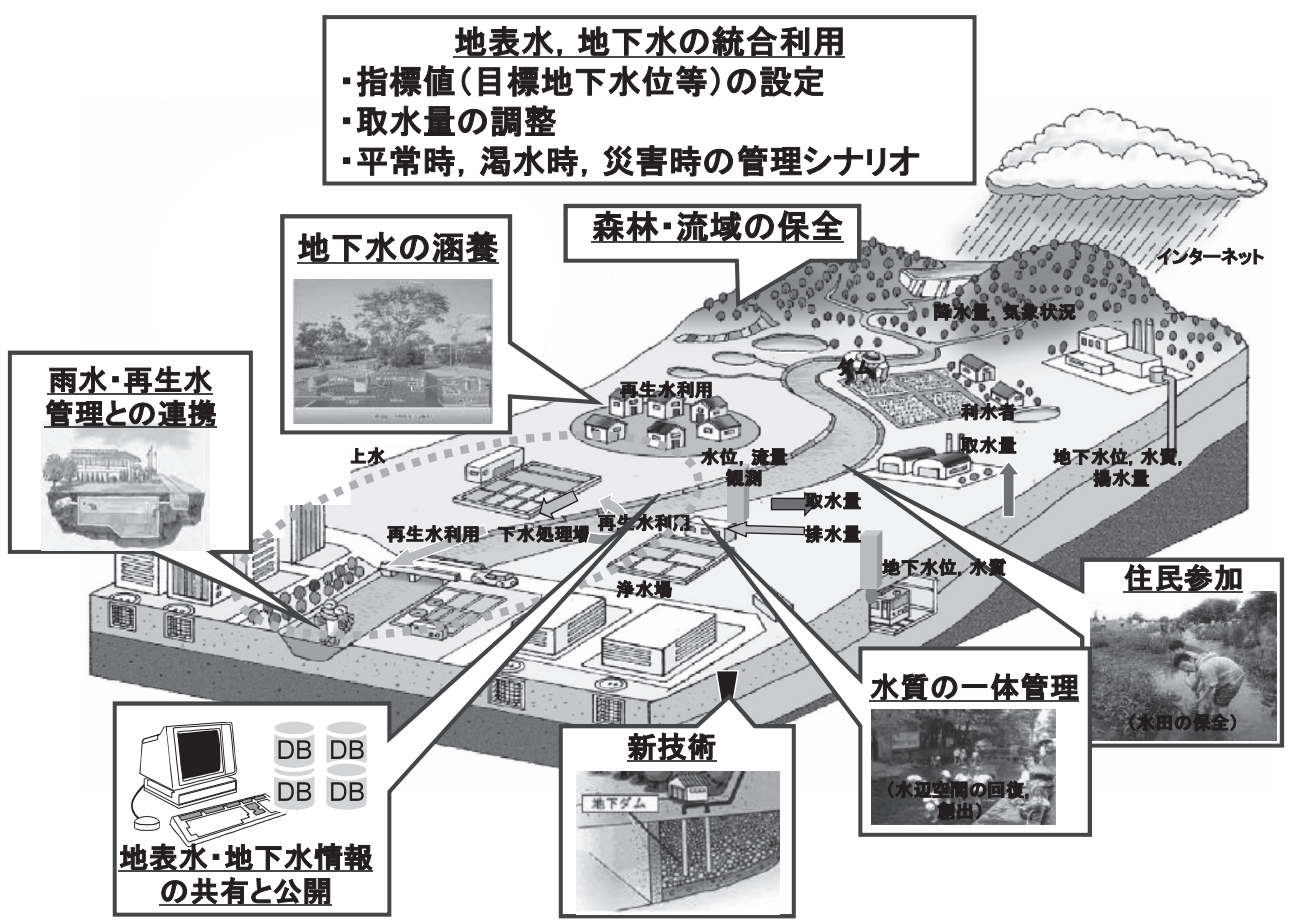

Fig. 9 Overview of integrated management of groundwater and surface water

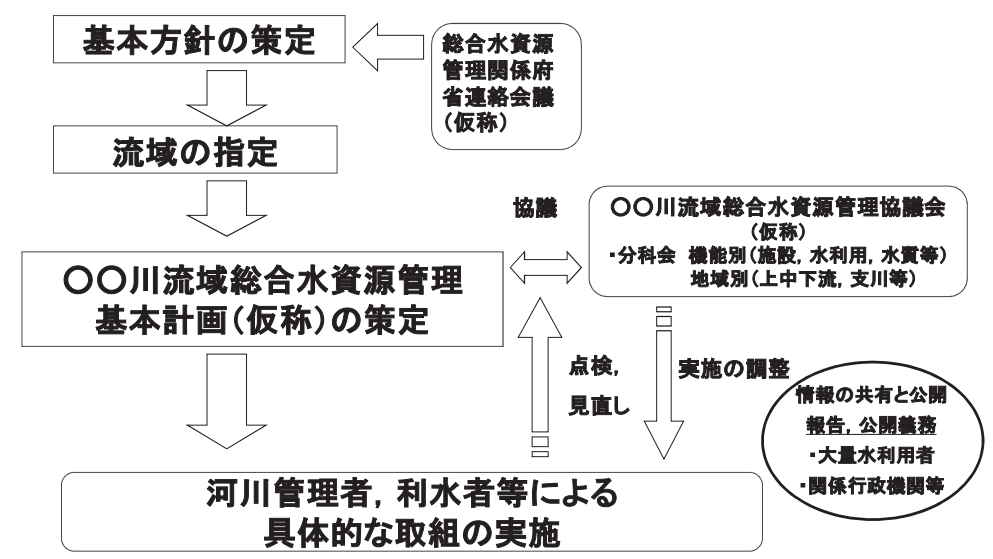

（国土審議会水資源分科会調査企画部会, 2008)

Fig. 10 Schematic picture of IWRM (example of a concept in Japan)

などの緊急時については，緊急的に水需要を抑制 することも考える)。こうしたシナリオによって 一時的な取水増やその後の涵養による回復などが 可能な地下水は，柔軟な総合水資源管理の実施に とり極めて有用な資源となり得る。
3．情報共有化と公開における地表水と地下水の 統合

情報の共有と公開は，統合水資源管理が機能 するかどうかの鍵を握っている。流域及び帯水層 単位の地下水の水位や水質, 揚水量などの情報を 地表水の諸量と統合し，利害関係者や住民と共有 


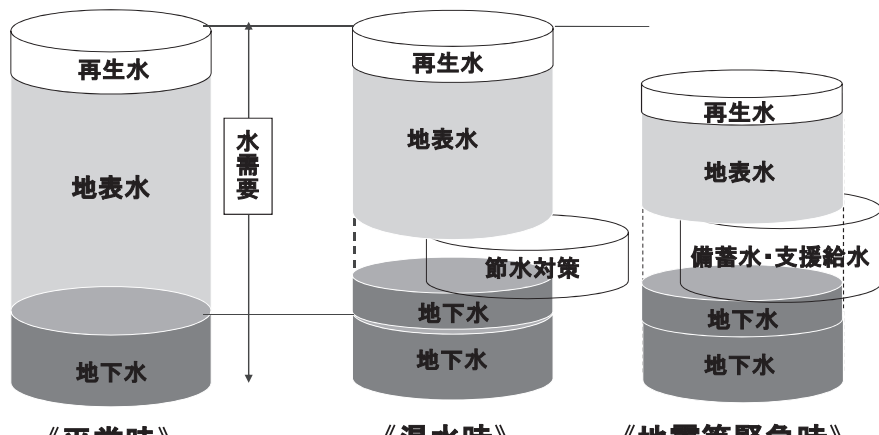

《平常時》

《渴水時》

《地震等緊急時》

Fig. 11 Scenario based IWRM

することにより，関係者が満足する地表水と地下 水の一体管理の姿を作り上げることが可能にな る。具体的には全てのデータを一箇所に格納する というより，Fig. 12 に示すように今まで独立し て構築されてきた水文・気象データ，地表水デー 夕, 地下水データなどをデータの標準化作業など を通じて連結可能にし，それらのデータベースを インターネットやクリアリングハウス等を通じて 結節，情報共有化し，総合水資源管理に関するシ ミュレーションなどに活用するものである。この 際，特に見えづらい地下水の情報をどう可視化す
るかに工夫が凝らされるべきである。また，総合 水資源シミュレーターにより様々な施策の効果を 表現し，複数のシナリオを提示することで, 利害 関係者間の速やかな合意形成を困ることも可能に なる。

4. 住民の参画と活動における地表水と地下水の 統合

日本も含め世界各地でコミュニティーによる地 下水の保全や活用に関する住民参加，住民活動が 行われている。各地で行われているこうした住民

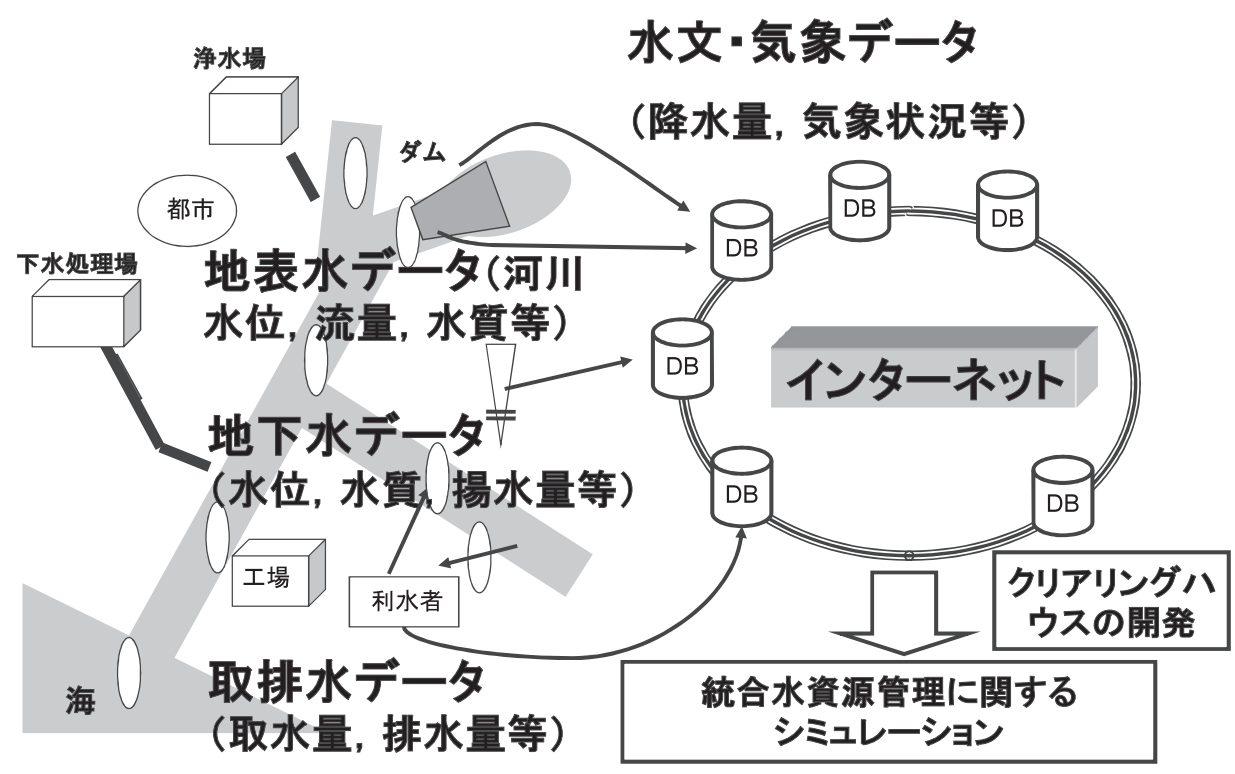

Fig. 12 Information sharing and disclosure of surface water and groundwater 
参加型の活動は，森林や流域の保全活動，河川の 保護活動など多岐にわたるが，最終的に地下水の 保全につながって打り，これらの活動が行政その ほかによる地下水に直接係わる活動と連携されて いくことが重要である。こうした住民活動同士の 連携や公的セクターと住民の連携などが, 統合水 資源管理の概念に即して展開すれば，極めて意義 のある活動となろう。

\section{$\mathrm{N}$ 地下水の統合管理を通じた国際貢献}

2002 年の国連持続可能な開発サミット実施計 画（JPOI）の中で，国連加盟国は統合水資源に 関する計画を各国が作成することで合意した。統 合水資源管理の実現へ向けた努力は各地域・国で 行われて打り，日本に扎いても2008年 10 月 1 日 に国土交通審議会水資源分科会調査企画部会に打 いて，地表水と地下水の一体管理などを柱とする 総合水資源管理についての中間とりまとめが発表 された。こうした取り組みをどのように世界，特 に発展途上地域と共有すれば良いだろうか。例え ば本年 3 月，ユネスコにより “実務レベルの統合 水資源管理ガイドライン”が発表された。こうし た現場のための実践マニュアルづくりに地下水に 係わる人々の㕡智が結集されれば，地下水科学は 人々の暮らしを直接潤すことになるであろう。

\section{V まとめ}

今まで述べてきたように，世界と日本の社会・ 暮らしは地下水に依存している。今後の人口変化 や気候変動は地下水への影響大, 過剩取水, 地盤 沈下，水質悪化等の影響が䯚念されており，地下 水に関係する組織や人が「地球規模で考え, ロー カルに行動する」必要が生じている。こうした中
で，統合水資源管理（IWRM）を通じた地表水と 地下水の統合管理は，地下水問題の解決に有効な 手法である。地表水と地下水の統合管理のために は，政策・制度，計画，情報共有·公開，住民参 加での統合が必須であるが，我が国には先進事例 となり得る多くの知見や具体的な実績も存在して いる。これらの知識や経験を有効に活用し，技術 や制度の改善を重ねることにより，日本は自らの 地下水管理を高め, 更に世界のより良い地下水管 理に貢献することが期待される。

\section{参考文献}

国土交通省土地・水資源局水資源部（2009）：日 本の水資源（水資源白書）平成 21 年版， $279 p$. 国土交通審議会水資源分科会調査企画部会 （2008）：「気候変動等によるリスクを踏まえた 総合的水資源マネジメント」について（中間と りまとめ), 26p.

地球環境戦略研究機関 IGES (2007)：IGES 白書, 274p.

気候変動に関する政府間パネル IPCC（2008）： 第 4 次評価報告書第 2 作業部会報告書, $75 \mathrm{p}$.

UNESCO-WWAP (2006) : World Water Development Report 2, 550p.

UNESCO (2009) : IWRM Guidelines at River Basin Level, 173p.

GWP TAC(2000): GWP Toolbox, 152p

(原稿受付：2010年 2 月 8 日) (原稿受理：2010年 3 月15日)

この論文に対する「討論」を2011年 2 月28日ま で受け付けます。 


\section{地下水と統合水資源管理}

\section{廣木 謙三}

\section{要 旨}

地球上の有限な資源である地下水は，身近にある便利な水資源として活用され てきた。しかし，人口爆発や気候変動といった地球規模の変化が，既に有る地球 上の地下水ストレスを拡大しつつある。統合水資源管理の概念を用いた地表水と 地下水の統合は非効率な水利用を減らし，柔軟な水資源開発を行うことにより持 続可能でより良い地下水管理を行うことが出来る。本稿では，地下水と地表水の 統合管理のために必要な 4 つのレべルにおける統合，すなわち法制度と政策面， 計画と実施面，住民参加面，情報共有と公開面においてどのような具体的な統合 を行い，どのような成果を期待できるかを概述する。また，こうした地下水の統 合管理による国際貢献についても言及する。

キーワード：地下水，統合水資源管理，気候変動，情報共有，住民参加 